\title{
Penguatan Budaya Hukum dalam Penyelenggaraan Pelayanan Publik sebagai Upaya Penegakan Hak Asasi Manusia (HAM) di Indonesia
}

\author{
Didik Sukriono ${ }^{14}$
}

\begin{abstract}
Abstrak
Penyelenggaraan pelayanan publik yang berasaskan: kepentingan umum, kepastian hukum, kesamaan hak, keseimbangan hak dan kewajiban, profesionalitas, partisipasi, persamaan perlakuan atau tidak diskriminatif, keterbukaan, kemudahan dan keterjangkauan, ternyata masih "cantik" di atas kertas tetapi "buruk" di tataran aplikasi. Upaya untuk mewujudkan penyelenggaraan pelayanan publik yang berkualitas cenderung memprioritaskan pembenahan substansi dan struktur hukum, tetapi kurang memperhatikan aspek budaya hukumnya, padahal budaya hukum merupakan "bensinnya motor keadilan" yang menentukan bagaimana seharusnya hukum itu berlaku dalam masyarakat. Artinya, nonsens pelayanan publik dapat ditegakkan tanpa didukung kesadaran, pengetahuan, dan pemahaman para subjek hukum dalam masyarakat. Oleh karena itu, penguatan budaya hukum dalam upaya perlindungan dan pemenuhan Hak Asasi Manusia (HAM) dalam pelayanan publik merupakan keniscayaan. Dengan demikian, penegakan hak-hak dasar setiap warga negara atas pemerintahan, perilaku administrasi dan kualitas pelayanan, sangat ditentukan oleh kesadaran masyarakat sendiri dalam memahami dan melaksanakan peraturan hukum pelayanan publik.
\end{abstract}

Kata Kunci: penguatan budaya hukum, pelayanan publik, penegakan HAM, budaya hukum, hak asasi manusia.

\section{Strengthening Legal Culture in Public Service to Enforce Human Rights in Indonesia}

\begin{abstract}
Law of public services shall be based on public interest, rule of law, equal rights, the balance of rights and obligations, professionality, participation, equal treatment or non-discrimination, accountability, special treatments, availability, and affordability, are "pretty" on paper but "ugly" in the implementation level. Efforts to achieve the quality of public services tends to prioritize the improvement of legal substance and structure of the law, but pay less attention to the cultural aspects of the law. Legal culture is a "fuel" of justice determine how the law should prevail in society. So it is nonsense that public services can be established without awareness, knowledge and understanding of the subject of law in society. Therefore, the strengthening of
\end{abstract}

14 Ketua Pusat Kajian Konstitusi (PKK) Fakultas Hukum Universitas Kanjuruhan Malang, Jl. S. Supriadi No. 48 Malang, didik_sukriono@yahoo.com, S.H. (Universitas Wisnuwarhana), M.Hum. (Universitas Brawijaya), Dr. (Universitas Brawijaya). 
Didik Sukriono: Penguatan Budaya Hukum dalam Penyelenggaraan Pelayanan Publik sebagai Upaya Penegakan Hak Asasi Manusia (HAM) di Indonesia

the legal culture in the protection and fulfillment of Human Rights (HAM) in public service is a necessity. Thus, the enforcement of the fundamental rights of every citizen in government, administrative behavior and quality of service, are determined by the people itself in understanding and implementing public service regulations.

Keywords: Strengthening legal culture, public service, human rights enforcement, legal culture, human rights.

\section{A. Pendahuluan}

Pemerintahan pada hakikatnya adalah pelayanan kepada masyarakat. Pemerintahan tidak diadakan untuk melayani dirinya sendiri, melainkan untuk melayani masyarakat dan menciptakan kondisi yang memungkinkan setiap anggota masyarakat untuk mengembangkan kemampuan dan kreativitasnya untuk mencapai tujuan bersama. ${ }^{1}$

Saat ini, paradigma penyelenggaraan pemerintahan telah mengalami pergeseran dari paradigma rule government menjadi good governance. Pemerintah dalam menyelenggarakan pemerintahan, pembangunan dan pelayanan publik dalam perspektif good governance, tidak semata-mata diserahkan kepada pemerintah (government) atau negara (state) saja, tetapi harus melibatkan seluruh komponen, yakni internal birokrasi maupun masyarakat.

Sedikitnya terdapat tiga alasan mengapa wacana good governance menjadi aktual, yaitu: (1) masih banyaknya korupsi dan berbagai bentuk penyimpangan dalam penyelenggaraan negara; (2) kebijakan otonomi daerah yang merupakan harapan besar bagi proses demokratisasi sekaligus kekhawatiran akan kegagalan program tersebut; dan (3) belum optimalnya pelayanan birokrasi pemerintah dan sektor swasta dalam memenuhi kebutuhan dan kepentingan publik. ${ }^{2}$

Secara konseptual, esensi tata kelola pemerintahan yang baik (good governance) dalam konteks penyelenggaraan pelayanan publik, adalah: (1) adanya kewajiban pada pihak aparatur negara untuk menjalankan fungsi dan kewenangannya berdasarkan prinsip-prinsip tata pemerintahan yang baik; (2) adanya pengakuan terhadap hak asasi setiap warga negara dan masyarakat atas pemerintahan, perilaku administratif, dan kualitas hasil pelayanan yang mumpuni; (3) adanya keanekaragaman jenis serta bidang dari pelayanan publik sebagai akibat dari adanya keragaman urusan dan kepentingan masyarakat yang harus dipenuhi melalui

1 M. Ryaas Rasjid, Desentralisasi dalam Menunjang Pembangunan Daerah dalam Pembangunan Administrasi di Indonesia, Jakarta: Pustaka LP3ES, 1998, hlm. 139.

2 Agung Hendarto dan Nizar Suhendra, Good Governance dan Penguatan Institusi Daerah, Jakarta: Masyarakat Transparansi Indonesia (MTI), 2002, hlm. vii. 
Didik Sukriono: Penguatan Budaya Hukum dalam Penyelenggaraan Pelayanan Publik sebagai Upaya Penegakan Hak Asasi Manusia (HAM) di Indonesia

penyelenggaraan pelayanan publik. ${ }^{3}$

Selanjutnya dalam Pasal 3 Undang-undang Nomor 25 Tahun 2009 tentang Pelayanan Publik (UUPP), secara spesifik dirumuskan tujuan UUPP sebagai berikut: (1) terwujudnya batasan dan hubungan yang jelas antara hak, tanggung jawab, kewajiban, dan kewenangan seluruh pihak yang terkait dengan penyelenggaraan pelayanan publik; (2) terwujudnya sistem pelayanan publik yang layak sesuai dengan asas-asas umum pemerintahan dan korporasi yang baik; (3) terpenuhinya penyelenggaraan pelayanan publik sesuai peraturan perundang-undangan, dan (4) terwujudnya perlindungan dan kepastian hukum bagi masyarakat dalam penyelenggaraan pelayanan publik.

Sasaran yang ingin dicapai dengan terbitnya UUPP adalah: (1) terwujudnya acuan hukum tentang penyelenggaraan pelayanan publik; (2) terwujudnya kepastian hukum bagi penyelenggaraan penanaman modal (investasi) di Indonesia; (3) terbentuk dan tersusunnya organisasi penyelenggara pelayanan publik yang layak; (4) terlaksananya pengelolaan sumber daya aparatur penyelenggara pelayanan publik yang efektif, tepat guna, dan tepat sasaran; (5) terwujudnya pengawasan dalam penyelenggaraan pelayanan publik; (6) terwujudnya peran serta masyarakat dalam penyelenggaraan pelayanan publik. ${ }^{4}$

Kinerja penyelenggara pelayanan publik, dilihat dari pola penyelenggaraan pelayanan, masih jauh dari cita UUPP, yakni: kurang responsif, kurang informatif, kurang accessible, kurang koordinatif, cenderung birokratis, tidak mau mendengar keluhan, kritik dan saran, serta inefisien. Sementara itu, dari Sumber Daya Manusia (SDM), nampak kurangnya profesionalisme, kompetensi, empati, dan etika. Lembaga Governance and Decentralization Survey menambahkan bahwa buruknya pelayanan publik ditandai dengan masih besarnya diskriminasi pelayanan, tidak adanya kepastian pelayanan, rendahnya tingkat kepuasan masyarakat, bahkan pelayanan cenderung menjadi 'komoditas'.

Hasil kajian Governance Assesment Survey (GAS) juga menunjukkan bahwa pemerintah belum dapat menyelenggarakan pelayanan dan kebijakan publik dengan baik. Hal ini ditandai dengan rendahnya aksesibilitas berbagai jenis pelayanan publik di daerah. Di berbagai daerah, masih banyak ditemukan penyelenggara pelayanan publik yang belum memiliki standar pelayanan dan ketidakpastian biaya serta waktu pelayanan. Ketidakpastian inilah yang menjadi penyebab munculnya praktik korupsi, kolusi, dan nepotisme (KKN) dalam penyelenggaraan pelayanan publik. Para pengguna jasa yang tidak sanggup menghadapi ketidakpastian cenderung memilih

3 Sirajjudin, Didik Sukriono dan Winardi, Hukum Pelayanan Publik Berbasis Partisipasi dan Keterbukaan Informasi, Malang: Setara Press (Kelompok Insrans Publishing), 2011, hlm. 7.

4 Ibid., hlm. 8. 
Didik Sukriono: Penguatan Budaya Hukum dalam Penyelenggaraan Pelayanan Publik sebagai Upaya Penegakan Hak Asasi Manusia (HAM) di Indonesia

membayar biaya yang lebih tinggi untuk memperoleh kepastian waktu dan kualitas pelayanan. Sebaliknya, situasi ini dimanfaatkan oleh penyelenggara pelayanan publik untuk memenuhi kepentingan dan kebutuhan pribadinya. ${ }^{5}$

Sepanjang tahun 2004-2011, Kementerian Dalam Negeri mencatat sebanyak 158 kepala daerah yang terdiri atas gubernur, bupati, walikota tersangkut korupsi. Sedikitnya 42 anggota DPR juga terseret korupsi pada kurun waktu 2008-2011 dan pada kurun waktu 2009-2011 tercatat 30 anggota DPR dari 4 parpol terlibat kasus dugaan suap pemilihan Deputi Gubernur Senior Bank Indonesia. Hal yang sama juga terjadi dalam institusi KPU, Komisi Yudisial, KPPU, Ditjen Pajak, Bank Indonesia, dan BKPM. Sepanjang tahun 2010, Mahkamah Agung menjatuhkan sanksi kepada 107 orang hakim, 288 orang pegawai kejaksaan, dan 294 orang polisi yang dipecat dari dinas Polri. ${ }^{6}$

Sunaryati ${ }^{7}$ secara spesifik mengelompokkan 20 bentuk maladministrasi, yaitu: kelompok pertama, bentuk maladministrasi yang terkait dengan ketepatan waktu dalam proses pelayanan umum, yang terdiri dari tindakan penundaan berlarut, tidak menangani, dan melalaikan kewajiban; kelompok kedua, bentuk maladministrasi yang mencerminkan keberpihakan sehingga menimbulkan rasa ketidakadilan dan diskriminasi, yang terdiri dari persekongkolan, kolusi, nepotisme, bertindak tidak adil, dan nyata-nyata tidak adil; kelompok ketiga, bentuk maladministrasi yang lebih mencerminkan bentuk pelanggaran hukum dan peraturan perundangan, yang terdiri dari pemalsuan, pelanggaran undang-undang, dan perbuatan melawan hukum; kelompok keempat, bentuk maladministrasi yang terkait dengan kewenangan/kompetensi atau ketentuan yang berdampak pada kualitas pelayanan umum pejabat publik kepada masyarakat, yang terdiri dari tindakan di luar kompetensi, pejabat yang tidak kompeten menjalankan tugas, intervensi yang memengaruhi proses pemberian pelayanan umum, dan tindakan yang menyimpang dari prosedur tetap; kelompok kelima, bentuk maladministrasi yang mencerminkan sikap arogansi seorang pejabat publik dalam proses pemberian pelayanan umum kepada masyarakat, yang terdiri dari tindakan sewenang-wenang, penyalahgunaan wewenang, tindakan yang tidak patut; kelompok keenam, bentuk maladministrasi yang mencerminkan tindakan korupsi secara aktif, yang terdiri dari tindakan pemerasan atau permintaan imbalan uang, penguasaan barang orang lain tanpa hak, dan penggelapan barang bukti.

5 Agus Dwiyanto (et.al.), Kinerja Tata Pemerintahan Daerah di Indonesia, Yogyakarta: PSKK UGM bekerja sama dengan Kemitraan, 2007, hlm. 17.

6 Kompas, Senin tanggal 20 Juni 2011, "Kerusakan Moral Mencemaskan”, hlm. 1, kolom 2.

7 C.F.G. Sunaryati Hartono, Panduan Investigasi untuk Ombudsman Indonesia, Jakarta, 2003, hlm. 18-22. 
Didik Sukriono: Penguatan Budaya Hukum dalam Penyelenggaraan Pelayanan Publik sebagai Upaya Penegakan Hak Asasi Manusia (HAM) di Indonesia

Permasalahannya ialah upaya perbaikan penyelengaraan pelayanan publik selama ini lebih menitikberatkan pada pembenahan substansi dan struktur hukum, tetapi lemah pada aspek budaya hukum. Lawrence Friedman menegaskan bahwa dalam upaya penegakan hukum, diperlukan pembenahan secara seimbang dari ketiga komponen tersebut. Sementara itu, Soerjono Soekanto menyatakan bahwa penegakan hukum meliputi komponen hukum, penegak hukum, kesadaran hukum masyarakat, serta sarana dan prasarana.

Berangkat dari permasalahan di atas, tulisan ini akan menguraikan tentang: konsep penegakan hukum, partisipasi masyarakat dalam pelayanan publik, dan upaya penguatan budaya hukum masyarakat dalam pelayanan publik.

\section{B. Konsep Penegakan Hukum Pelayanan Publik}

Penegakan hukum (law enforcement) merupakan rangkaian proses untuk menjabarkan nilai, ide, cita, dan selanjutnya menjadi tujuan hukum. Cita hukum atau tujuan hukum memuat nilai-nilai moral, yakni keadilan (Rechtsvaardigheid), kepastian (Rechtszekerheid), dan kemanfaatan (Doelmatigheid). ${ }^{8}$ Eksistensi hukum diakui apabila nilai-nilai moral yang terkandung dalam hukum tersebut mampu diimplementasikan. Kegagalan hukum untuk mewujudkan nilai hukum tersebut merupakan ancaman akan "bangkrutnya" hukum yang ada. Hukum yang "miskin" implementasi terhadap nilai-nilai moral akan berjarak dan terisolasi dari masyarakatnya.

Inti dan arti dari penegakan hukum secara konsepsional terletak pada kegiatan menyelaraskan hubungan nilai-nilai yang dijabarkan dalam kaidah-kaidah dan mengejawantahkan sikap dan tindak sebagai rangkaian penjabaran nilai tahap akhir untuk menciptakan, memelihara, dan mempertahankan kedamaian dalam pergaulan hidup. ${ }^{9}$ Sejalan dengan itu, Solahuddin Wahid berpendapat bahwa penegakan hukum adalah upaya penyelesaian persoalan-persoalan yang didasarkan pada prinsip-prinsip dan nilai-nilai yang terkandung dalam kaidah-kaidah hukum tersebut. Barda Nawawi Arief mengatakan bahwa penegakan hukum pada hakikatnya adalah perlindungan hak asasi manusia, serta tegaknya kebenaran dan keadilan, dan tidak adanya penyalahgunaan kekuasaan dan praktik favoritisme, yang diwujudkan dalam seluruh norma atau tatanan kehidupan masyarakat

Dalam praktiknya, cita atau ide kepastian hukum, keadilan, dan kemanfaatan hampir tidak mungkin diraih ketiga-tiganya secara seimbang. Jika kepastian hukum merupakan salah satu arah pendulum penegakan hukum, maka arah pendulum yang lain, yaitu keadilan dan kemanfaatan akan berkurang, begitu juga sebaliknya.

8 Soedjono Dirdjosisworo, Pengantar Ilmu Hukum, Jakarta: CV. Rajawali, 1984, hlm. 127.

9 Satjipto Rahardjo, Penegakan Hukum: Suatu Tinjauan Sosiologis, Yogyakarta: Genta Publishing, 2009, hlm. vii. 
Didik Sukriono: Penguatan Budaya Hukum dalam Penyelenggaraan Pelayanan Publik sebagai Upaya Penegakan Hak Asasi Manusia (HAM) di Indonesia

Penekanan pada salah satu aspek baik kepastian atau keadilan sangat dipengaruhi oleh tradisi hukum yang dianut. Negara yang menganut Civil Law tradition yang berpangkal pada hukum dan perundang-undangan akan mengarah pada kepastian hukum; sedangkan negara yang menganut tradisi Common Law tradition yang berpangkal pada custom and case law, maka rasa keadilan masyarakat lebih terakomodasi melalui judge made law. Selain aspek kepastian dan keadilan, dalam penegakan hukum juga harus diperhatikan aspek kemanfaatan atau kegunaan hukum masyarakat, jangan sampai karena hukum dilaksanakan atau ditegakkan malah timbul keresahan dalam masyarakat, sebab hukum itu untuk masyarakat dan bukan masyarakat untuk hukum.

Penegakan hukum sebagai suatu proses pada hakikatnya merupakan variabel yang mempunyai korelasi dan interdependensi dengan faktor-faktor yang lain. Lawrence M Friedman mengungkapkan tiga faktor yang menentukan proses penegakan hukum, yaitu komponen substansi, struktur, dan kultural. Ketiga komponen tersebut merupakan suatu sistem, artinya komponen-komponen itu akan sangat menentukan proses penegakan hukum dalam masyarakat dan tidak dapat dinafikan satu dengan yang lainnya. Kegagalan pada salah satu komponen akan berimbas pada faktor lainnya.

Sementara itu menurut Abdul Mukthie Fadjar, terdapat empat faktor yang harus diperhatikan dalam menegakkan hukum pelayanan publik untuk dapat mendekati tercapainya kepastian, keadilan, dan kemanfaatan, yaitu: (1) faktor substansial kaidah hukumnya; (2) faktor struktural, yaitu aparatur penegak hukumnya; (3) faktor kultural, dalam hal ini kesadaran hukum para "justiciabel"; dan (4) faktor manajerial, dalam hal ini administrasi pengelolaan organisasinya. ${ }^{10}$

Berdasarkan faktor substansial, peraturan hukum yang akan ditegakkan (kaidah) harus jelas dan tegas serta tidak mengandung multi interpretasi. Oleh karena itu, dalam pembuatan undang-undang harus memperhatikan aspek-aspek filosofis (nilainilai dan asas-asas yang dicitakan masyarakat), yuridis (prosedur pembuatannya benar dan tidak saling bertentangan satu sama lain), dan sosiologis (sesuai dengan realitas dan tuntutan masyarakat). Pertanyaannya adalah apakah peraturan perundang-undangan yang berkaitan dengan penyelenggaraan pelayanan publik sudah memenuhi persyaratan substansial kaidah hukum atau belum.

Faktor struktural sangat ditentukan oleh aparatur penegak hukumnya, yaitu orang-orang atau pejabat-pejabat yang secara langsung berhubungan dengan pelaksanaan, pemeliharaan, usaha untuk mempertahankan hukum dan apabila

10 Abdul Mukthie Fadjar, "Keprihatinan Memudarnya Penegakan Hukum dan Kewibawaan Hukum di Indonesia", Makalah disampaikan pada Sarasehan Forum Doktor Fakultas Hukum Universitas Brawijaya, 30 Juni 2011, hlm. 3. 
Didik Sukriono: Penguatan Budaya Hukum dalam Penyelenggaraan Pelayanan Publik sebagai Upaya Penegakan Hak Asasi Manusia (HAM) di Indonesia

dipandang perlu sesuai dengan fungsinya yang diatur oleh undang-undang, dapat memaksakan berlakunya hukum. Persyaratan yang harus dipenuhi oleh seorang penegak hukum yang baik, di antaranya: harus menguasai makna kaidah-kaidah hukum yang ada, baik tertulis maupun tidak tertulis; memiliki pengetahuan dan wawasan yang luas; dapat mengikuti perkembangan masyarakat dan kebutuhannya; harus mengetahui batas wewenangnya, serta mempunyai keterampilan dalam melaksanakan tugasnya; dan tentunya memiliki integritas atau kejujuran. Penegak hukum yang lazim dikenal adalah pengadilan, kejaksaan, kepolisian, dan advokat yang disebut sebagai catur wangsa penegak hukum, bahkan instansi pemerintah yang terkait dengan penerapan hukum juga dapat dikategorikan sebagai penegak hukum. ${ }^{11}$

Faktor kultural disyaratkan adanya kesadaran hukum (keinsyafan) anggota masyarakat untuk menghindari perbuatan-perbuatan yang dilarang, melaksanakan tugas dan kewajiban sebagai warga masyarakat, dan mengerti akibat-akibat hukumnya jika melanggar hukum. Kesadaran hukum para 'justiciabel' sangat dipengaruhi oleh kebudayaan, pengetahuan, dan tingkat pendidikan masyarakat. Kesadaran hukum para "justiciabel" merupakan jembatan yang menghubungkan antara peraturan-peraturan hukum dengan perilaku hukum seseorang. Hal ini termasuk dalam kategori nilai-nilai serta sikap-sikap yang memengaruhi bekerjanya hukum dalam masyarakat, yang disebut juga sebagai budaya hukum.

Faktor manajerial berkaitan dengan proses mengoordinasikan dan mengintegrasikan faktor-faktor yang menentukan efektif atau tidaknya penegakan ide (tujuan) hukum dalam penyelenggaraan pelayanan publik, yaitu faktor hukum (undang-undang), penegak hukum, sarana atau fasilitas, dan budaya hukum masyarakat. Dengan demikian, berhasil tidaknya penegakan hukum memang tidak ditentukan oleh satu faktor saja, tetapi juga setidak-tidaknya oleh keempat faktor tersebut secara proporsional.

Upaya yang dikembangkan oleh penyelenggara negara dalam mewujudkan kualitas penyelenggaraan pelayanan publik cenderung memperhatikan faktor substansi dan struktur hukum saja tetapi kurang memperhatikan faktor budaya hukumnya. Friedman ${ }^{12}$ mengingatkan bahwa budaya hukum yang berupa keseluruhan sikap dan sistem nilai dari masyarakat dan kesadaran hukum masyarakat, merupakan "bensinnya motor keadilan" yang menentukan bagaimana seharusnya hukum itu berlaku dalam masyarakat. Artinya, nonsens hukum pelayanan publik dapat ditegakkan tanpa didukung oleh kesadaran, pengetahuan, dan pemahaman para subjek hukum dalam masyarakat.

11 Ibid., hlm. 3.

12 Lawrence M. Friedman, "Legal Culture and Social Development", Law and Society, Vol. 4, 1969, hlm. 9 
Didik Sukriono: Penguatan Budaya Hukum dalam Penyelenggaraan Pelayanan Publik sebagai Upaya Penegakan Hak Asasi Manusia (HAM) di Indonesia

Hal lain yang tidak kalah penting adalah adanya suatu tingkat otonomi tertentu bagi organisasi (lembaga-lembaga penyelenggara pelayanan publik) dalam mewujudkan ide-ide (tujuan) hukum penyelenggaraan pelayanan publik. Otonomi tersebut diperlukan dalam rangka mengelola sumber daya yang tersedia, yaitu: sumber daya manusia, sumber daya fisik, sumber daya keuangan, dan sumber daya lainnya yang dibutuhkan untuk menggerakkan organisasi.

\section{Partisipasi Masyarakat dalam Pelayanan Publik}

Partisipasi dapat diartikan sebagai ikut serta, berperan serta dalam suatu kegiatan, mulai dari perencanaan sampai dengan evaluasi. Dalam perspektif politik, Huntington ${ }^{13}$ dan Nelson memberikan pengertian partisipasi politik sebagai kegiatan warga negara sipil (civilians) yang bertujuan memengaruhi pengambilan keputusan oleh pemerintah. Kelompok Belajar Partisipasi Bank Dunia merumuskan partisipasi masyarakat sebagai suatu proses melalui stakeholder yang memengaruhi dan ikut berbagi (share) kontrol atas prakarsa dan keputusan serta sumber daya pembangunan yang memengaruhi mereka. ${ }^{14}$

Konsepsi di atas dipercaya mampu menjamin keadilan demokrasi, yaitu bahwa semua warga negara akan diperlakukan sama dalam penyelenggaraan negara. Persamaan tersebut mengimplikasikan bahwa semua lapisan masyarakat mempunyai hak terhadap akses dalam proses penyelenggaraan pemerintahan tanpa ada perbedaan. Prinsip keadilan demokrasi dalam penyelenggaraan pemerintahan merupakan hak asasi bagi warga negara yang kemudian berimplikasi pada kewajiban bagi setiap negara untuk menjamin keberlangsungannya. Kovenan Internasional HakHak Sipil dan Politik yang ditetapkan oleh Resolusi Majelis Umum PBB 2200 A (XXI) dalam Pasal 25 ditentukan bahwa: "Setiap warga negara harus mempunyai hak dan kesempatan tanpa pembedaan apapun". Ketentuan serupa juga terdapat dalam Undang-undang Nomor 39 Tahun 1999 tentang Hak Asasi Manusia, bagian kedelapan tentang hak turut serta dalam pemerintahan (Pasal 43). Ketentuan-ketentuan itu merupakan landasan penting bagi masyarakat yang memberikan kesempatan untuk melaksanakan hak asasinya dalam partisipasi publik pada proses penyelenggaraan pemerintahan yang demokratis di Indonesia.

Sherry Arnstein sebagaimana dikutip oleh Rival G. Ahmad ${ }^{15}$ dalam A Ladder of Citizen Participation membuat skema 8 (delapan) tingkat partisipasi rakyat dalam

13 Samuel P. Huntington dan Joan Nelson, Partisipasi Politik di Negara Berkembang, Jakarta: Rineka Cipta, 1994, hlm. 18.

14 Manajemen Prasarana dan Sarana Perkotaan (MPSP), “Partisipasi Masyarakat dalam Perencanaan dan Pemrograman Pembangunan Prasaran dan Sarana Perkotaan (Modul Peserta)", Pemkot Malang Bekerja sama dengan USAID, 2002.

15 Rival G. Ahmad (et.al.), "Dari Parlemen ke Ruang Publik: Menggagas Penyusunan Kebijakan Partisipatif”, Jurnal Hukum Jentera, Edisi ke 2, 2003, hlm. 109. 
Didik Sukriono: Penguatan Budaya Hukum dalam Penyelenggaraan Pelayanan Publik sebagai Upaya Penegakan Hak Asasi Manusia (HAM) di Indonesia

memutuskan kebijakan. Tingkat tertinggi atau pertama adalah kontrol warga negara (citizen control). Tingkat kedua delegasi kewenangan (delegated power), pada tingkat ini kewenangan masyarakat lebih besar daripada penyelenggara negara dalam merumuskan kebijakan. Tingkat ketiga, kemitraan (partnership) yaitu adanya keseimbangan kekuatan relatif antara masyarakat dan pemegang kekuasaan untuk merencanakan dan mengambil keputusan bersama-sama. Tingkat keempat sampai keenam mengindikasikan partisipasi semu yang terdiri dari peredaman (placation), konsultasi dan informasi (informing). Tingkat ketujuh dan kedelapan, terapi dan manipulasi yang menunjukkan ketiadaan partisipasi. Di tangga terapi kelompok kebijakan masyarakat, korban kebijakan dianjurkan mengadu kepada pihak yang berwenang tetapi tidak jelas pengaduan tersebut ditindaklanjuti atau tidak. Celakanya, di tangga manipulasi lembaga negara melakukan pembenar terhadap kelompok-kelompok masyarakat untuk seolah-olah berpartisipasi padahal sejatinya yang terjadi adalah kooptasi dan represi penguasa.

Sementara itu, Wilcox dalam Purwanto ${ }^{16}$ membedakan level partisipasi masyarakat menjadi lima jenis, yaitu pemberian informasi, konsultasi, pembuatan keputusan bersama, melakukan tindakan bersama, dan mendukung aktivitas yang muncul atas swakarsa masyarakat. Menurut Wilcox, pada level partisipasi masyarakat akan dilakukan sangat bergantung pada kepentingan apa yang hendak dicapai. Untuk pengambilan kebijakan strategis yang memengaruhi hajat hidup orang banyak, masyarakat tentu harus dilibatkan secara penuh. Sementara dalam pengambilan keputusan yang bersifat teknis, pemberian informasi kepada masyarakat sudah sangat memadai.

Apabila digambarkan abstraksinya secara umum, peran serta masyarakat dalam konteks penyelenggaraan negara berdasarkan Peraturan Pemerintah Nomor 68 Tahun 1999 mengandung hak-hak dan kewajiban sebagai berikut: (1) hak mencari, memperoleh, dan memberikan informasi mengenai penyelenggaraan negara; (2) hak untuk memperoleh pelayanan yang sama dan adil dari penyelenggara negara; (3) hak untuk menyampaikan saran dan pendapat secara bertanggung jawab terhadap kebijakan penyelenggaraan negara; (4) hak untuk memperoleh perlindungan hukum dalam hal melaksanakan haknya dan apabila diminta hadir dalam proses penyelidikan, penyidikan, dan persidangan sebagai saksi pelapor, saksi atau saksi ahli sesuai dengan ketentuan peraturan perundang-undangan yang berlaku; (5) hak-hak tersebut dilaksanakan sesuai dengan ketentuan peraturan perundang-undangan yang berlaku dan menaati norma sosial lainnya. Hal ini dimaksudkan untuk

16 Erwan Agus Purwanto, "Pelayanan Publik Partisipatif", dalam buku Mewujudkan Good Governance yang disusun oleh Agus Dwiyanto, Yogyakarta: Gajah Mada, 2005, hlm. 192. 
Didik Sukriono: Penguatan Budaya Hukum dalam Penyelenggaraan Pelayanan Publik sebagai Upaya Penegakan Hak Asasi Manusia (HAM) di Indonesia

menghindari fitnah dan laporan yang tidak bertanggung jawab; (6) kesadaran hukum masyarakat dan penegak hukum dalam semangat yang interaktif antara kesadaran hukum versi penguasa di satu sisi dan perasaan hukum khususnya persepsi keadilan yang bersifat spontan dari masyarakat di sisi lain.

Pertanyaannya ialah mengapa partisipasi masyarakat dalam penyelenggaraan pelayanan publik menjadi suatu keharusan. Irfan Islamy menyatakan paling tidak ada 8 (delapan) manfaat yang akan dicapai jika melibatkan partisipasi masyarakat dalam proses pembangunan, yaitu: pertama, masyarakat akan semakin siap untuk menerima dan melaksanakan gagasan pembangunan; kedua, hubungan masyarakat, pemerintah, dan legislatif akan semakin baik; ketiga, masyarakat mempunyai komitmen yang tinggi terhadap institusi; keempat, masyarakat akan mempunyai kepercayaan yang lebih besar kepada pemerintah dan legislatif serta bersedia bekerja sama dalam penanganan tugas dan urusan publik; kelima, bila masyarakat telah memiliki kepercayaan dan menerima ide-ide pembangunan, maka mereka juga akan merasa ikut memiliki tanggung jawab untuk turut serta mewujudkan ide-ide tersebut; keenam, mutu/kualitas keputusan atau kebijakan yang diambil akan menjadi semakin baik karena masyarakat turut serta memberikan masukan; ketujuh, akan memperlancar komunikasi dari bawah ke atas dan dari atas ke bawah; dan kedelapan, dapat memperlancar kerja sama terutama untuk mengatasi masalahmasalah bersama yang kompleks dan rumit. ${ }^{17}$

Oleh karena itu, hak masyarakat untuk berpartisipasi dalam penyelenggaraan pelayanan publik secara tegas dijamin dalam Pasal 39 UUPP sebagai berikut:

(1) Peran serta masyarakat dalam penyelenggaraan pelayanan publik dimulai sejak penyusunan standar pelayanan sampai evaluasi dan pemberian penghargaan.

(2) Partisipasi masyarakat sebagaimana dimaksud pada ayat (1) diwujudkan dalam bentuk kerja sama, pemenuhan hak dan kewajiban masyarakat, serta peran aktif dalam penyusunan kebijakan pelayanan publik.

(3) Masyarakat dapat membentuk lembaga pengawasan pelayanan publik.

(4) Tata cara pengikutsertaan masyarakat dalam pelayanan publik diatur lebih lanjut dalam peraturan pemerintah.

Keterlibatan masyarakat mengawal penyelenggaraan pelayanan publik juga semakin kuat setelah lahirnya Undang-undang Nomor 14 Tahun 2009 tentang Keterbukaan Informasi Publik (UU KIP). Legalitas keterlibatan masyarakat dapat dilihat dari tujuan UU KIP, yaitu: (1) menjamin hak warga negara untuk mengetahui rencana pembuatan kebijakan publik, program kebijakan publik, dan proses

17 Irfan Islamy, "Membangun Masyarakat Partisipatif”, Jurnal Administrasi Publik, Vol. IV No. 2, 2004, hIm. 3-9. 
Didik Sukriono: Penguatan Budaya Hukum dalam Penyelenggaraan Pelayanan Publik sebagai Upaya Penegakan Hak Asasi Manusia (HAM) di Indonesia

pengambilan keputusan publik, serta alasan pengambilan suatu keputusan publik; (2) mendorong partisipasi masyarakat dalam proses pengambilan kebijakan publik; (3) meningkatkan peran aktif masyarakat dalam pengambilan kebijakan publik dan pengelolaan badan publik yang baik; (4) mewujudkan penyelenggaraan negara yang baik, yaitu transparan, efektif dan efisien, akuntabel serta dapat dipertanggungjawabkan; (5) mengetahui alasan kebijakan publik yang memengaruhi hajat hidup orang banyak; (6) mengembangkan ilmu pengetahuan dan mencerdaskan kehidupan bangsa; dan/atau (7) meningkatkan pengelolaan dan pelayanan informasi di lingkungan badan publik untuk menghasilkan layanan informasi yang berkualitas.

Sebelum lahirnya UU KIP, terdapat beberapa peraturan perundang-undangan yang juga mengatur secara sporadis perihal kebebasan memperoleh informasi, yakni:

1. Dalam Pasal 4 ayat (2) Undang-undang Nomor 24 Tahun 1992 tentang Tata Ruang, disebutkan bahwa: "Setiap orang berhak untuk mengetahui rencana tata ruang".

2. Dalam Pasal 5 ayat (2) Undang-undang Nomor 23 Tahun 1997 tentang Lingkungan Hidup, dinyatakan bahwa: "Setiap orang mempunyai hak atas informasi lingkungan hidup yang berkaitan dengan peran dalam pengelolaan lingkungan".

3. Undang-undang Nomor 28 Tahun 1999 tentang Penyelenggaraan Negara yang Bersih dan Bebas KKN. Dalam Pasal 3, ditegaskan bahwa: "Asas-asas umum penyelenggaraan negara meliputi Asas Keterbukaan", Dalam Pasal 5, dirinci perihal: "Setiap penyelenggara negara berkewajiban untuk: ayat (3): bersedia diperiksa kekayaannya sebelum, selama, dan setelah menjabat; ayat (4): melaporkan dan mengumumkan kekayaannya sebelum dan setelah menjabat". Sedangkan dalam Pasal 9 ayat (1) diatur mengenai: "Peran serta masyarakat sebagaimana dimaksud dalam pasal 8 diwujudkan dalam bentuk (a) hak mencari, memperoleh, dan memberikan informasi tentang penyelenggaraan negara".

4. Dalam Pasal 41 ayat (1) Undang-undang Nomor 31 Tahun 1999 tentang Pemberantasan Tindak Pidana Korupsi, dinyatakan sebagai berikut: "Peran serta masyarakat diwujudkan dalam bentuk: (a) hak mencari, memperoleh dan memberikan informasi adanya dugaan telah terjadi tindak pidana korupsi; (b) hak untuk memperoleh pelayanan dalam mencari, memperoleh dan memberikan informasi adanya dugaan telah terjadi tindak pidana korupsi kepada penegak hukum yang menangani perkara tindak pidana korupsi; (c) hak menyampaikan saran dan pendapat secara bertanggung jawab kepada penegak hukum yang menangani perkara tindak pidana korupsi; (d) hak untuk memperoleh jawaban atas pertanyaan tentang laporannya yang diberikan kepada penegak hukum dalam waktu paling lama 30 (tiga puluh) hari". 
Didik Sukriono: Penguatan Budaya Hukum dalam Penyelenggaraan Pelayanan Publik sebagai Upaya Penegakan Hak Asasi Manusia (HAM) di Indonesia

5. Undang-undang Nomor 39 Tahun 1999 tentang Hak Asasi Manusia. Dalam Pasal 14 ayat (1) dan (2), dinyatakan bahwa: "Setiap orang berhak untuk berkomunikasi dan memperoleh informasi yang diperlukan untuk mengembangkan pribadi dan lingkungan sosialnya; Setiap orang berhak untuk mencari, memperoleh, memiliki, menyimpan, mengolah, dan menyampaikan informasi dengan menggunakan segala jenis sarana yang tersedia". Sedangkan dalam Pasal 90 ayat (1) diatur: "Setiap orang dan/atau kelompok orang yang memiliki alasan kuat bahwa hak asasinya telah dilanggar dapat mengajukan laporan dan pengaduan lisan atau tertulis pada Komnas HAM".

6. Undang-Undang Nomor 32 Tahun 2004 tentang Pemerintahan Daerah. Dalam Pasal 20 ayat (1), dinyatakan bahwa: "Penyelenggaraan pemerintahan berpedoman pada asas umum penyelenggaraan negara yang terdiri atas: $d$. asas keterbukaan". Sedangkan dalam Pasal 139 ayat (1) dikemukakan bahwa: "Masyarakat berhak memberikan masukan secara lisan atau tertulis dalam rangka penyiapan atau pembahasan rancangan Perda".

7. Undang-undang Nomor 10 Tahun 2004 tentang Pembentukan Peraturan Perundang-undangan sebagaimana telah digantikan oleh Undang-undang Nomor 12 Tahun 2011 tentang Pembentukan Peraturan Perundang-Undangan. Dalam Pasal 5, dinyatakan sebagai berikut: “Dalam membentuk peraturan perundang-undangan, harus didasarkan pada asas pembentukan peraturan perundang-undangan yang baik, yang meliputi: keterbukaan". Yang dimaksud dengan asas keterbukaan yang dimaksud adalah dalam proses pembentukan peraturan perundang-undangan -mulai dari perencanaan, persiapan, penyusunan, dan pembahasan- bersifat transparan dan terbuka.

\section{Penguatan Budaya Hukum Masyarakat}

Secara etimologis, penguatan berasal dari kata "kuat" yang mempunyai arti banyak tenaganya atau kemampuan yang lebih, sedangkan kata "penguatan" mempunyai arti perbuatan, hal dan lain sebagainya yang menguati atau menguatkan. Secara terminologis, penguatan mempunyai makna usaha menguatkan sesuatu atau hal yang tadinya lemah menjadi lebih kuat. Penguatan ini didasari karena adanya sesuatu yang lemah untuk dijadikan kuat sehingga dilakukan proses penguatan.

Penguatan terbagi ke dalam dua jenis yaitu penguatan positif dan penguatan negatif. Arah dan tujuan kedua jenis penguatan itu sama, yaitu mendorong lebih kuatnya tingkah laku baik yang telah ditampilkan tetapi dengan bentuk dan materi penguatan yang berbeda. Penguatan positif diselenggarakan dengan jalan pemberian hal-hal positif berupa pujian, hadiah, atau hal-hal lain yang berharga kepada pelaku perbuatan yang dianggap baik dan ingin ditingkatkan frekuensi penampilannya. Sementara itu, penguatan negatif diselenggarakan dengan 
Didik Sukriono: Penguatan Budaya Hukum dalam Penyelenggaraan Pelayanan Publik sebagai Upaya Penegakan Hak Asasi Manusia (HAM) di Indonesia

mengurangi hal-hal tertentu yang menyenangkan bagi si pelaku, dengan cara mengurangi hal-hal tertentu yang selama ini dirasakan sebagai hukuman, tidak menyenangkan, atau menjadi sesuatu yang memberatkan bagi si pelaku.

Sejalan dengan konsep penguatan dalam konteks ini adalah penyuluhan yaitu upaya untuk meningkatkan pengetahuan, keterampilan dan sikap, melalui pemberdayaan masyarakat (Community Empowerment), penguatan kapasitas (Capacity Strenghtening), dan komunikasi pembangunan. Dalam hal ini, memberdayakan berarti memberi daya kepada yang tidak berdaya dan/atau mengembangkan daya yang sudah dimiliki menjadi sesuatu yang lebih bermanfaat bagi masyarakat yang bersangkutan. Penguatan kapasitas adalah penguatan kemampuan yang dimiliki oleh setiap individu (dalam masyarakat), kelembagaan, maupun hubungan atau jejaring antar individu, kelompok organisasi sosial, serta pihak lain di luar sistem masyarakatnya sampai di aras global; sedangkan komunikasi pembangunan adalah upaya untuk menyampaikan pesan-pesan pembangunan, tetapi yang lebih penting dari itu adalah untuk menumbuhkembangkan partisipasi masyarakat dalam pembangunan.

Tujuan penguatan dalam konteks penguatan budaya hukum penyelenggaraan pelayanan publik, antara lain:

1. Sosialisasi, yakni penyebaran substansi UUPP yang menyangkut lingkup pelayanan publik, hak-hak masyarakat yang dijamin, kewajiban penyelenggara pelayanan serta sanksi jika terjadi pelanggaran oleh penyelenggara layanan kepada masyarakat agar mempunyai pengetahuan, pengertian, dan pemahaman sesuai yang diharapkan UUPP.

2. Optimalisasi artinya substansi UUPP yang telah ditransformasikan diharapkan dapat dipahami, diketahui, diyakini, dan dilaksanakan secara menyeluruh atau maksimal.

3. Peningkatan, yaitu penguatan yang dilakukan sebagai upaya meningkatkan pengetahuan, pengertian, dan pemahaman masyarakat tentang UUPP agar penyelenggaraan pelayanan publik dapat dilaksanakan sesuai dengan napas dan amanat dari UUPP.

4. Pembaharuan, yaitu perubahan budaya dalam penyelenggaraan pelayanan publik yang berbeda dengan sebelumnya menjadi lebih baik dan meningkat sesuai dengan asas-asas penyelenggaraan pelayanan publik.

Upaya penguatan budaya hukum, pada hakikatnya juga merupakan upaya penguatan kesadaran hukum masyarakat. Artinya, budaya hukum dan kesadaran hukum masyarakat merupakan satu kesatuan yang tidak dapat dipisahkan dan keduanya sangat berhubungan dengan pelaksanaan hukum dalam masyarakat. Hukum yang dibuat itu sekalipun memenuhi persyaratan yang ditentukan secara filosofis dan yuridis, tetapi jika kesadaran hukum masyarakat tidak mempunyai 
Didik Sukriono: Penguatan Budaya Hukum dalam Penyelenggaraan Pelayanan Publik sebagai Upaya Penegakan Hak Asasi Manusia (HAM) di Indonesia

respon untuk menaati dan mematuhi peraturan hukum tersebut, maka peraturan hukum yang dibuat tidak akan efektif berlakunya. Singkatnya, kesadaran hukum para "justiciabel" merupakan jembatan yang menghubungkan antara peraturanperaturan hukum dengan perilaku hukum seseorang.

Satjipto Rahardjo ${ }^{18}$ menegaskan bahwa penegakan hukum selalu melibatkan manusia dan tingkah laku manusia. Hukum tidak dapat tegak dengan sendirinya, yakni hukum tidak mampu mewujudkan sendiri janji-janji serta kehendak-kehendak yang tercantum dalam peraturan-peraturan hukum. Solly Lubis ${ }^{19}$ menambahkan, kesadaran hukum merupakan panduan sikap mental dan tingkah laku terhadap masalah-masalah yang mempunyai segi hukum yang meliputi pengetahuan mengenai seluk-beluk hukum, penghayatan atau internalisasi terhadap nilai-nilai keadilan dan ketaatan atau kepatuhan terhadap hukum yang berlaku. Sementara itu, tingkat kesadaran adalah bobot pengetahuan, penghayatan, dan ketaatan terhadap hukum yang berlaku yang diperlihatkan oleh cara-cara berpikir dan berbuat dalam pergaulan sehari-hari.

Merujuk pada pendapat di atas, dapat dikatakan bahwa budaya hukum dan kesadaran hukum masyarakat menjadi parameter utama dalam proses penegakan hukum. Indikator keberhasilan implementasi hukum, bukan karena sanksi ataupun rasa takut, melainkan kesadaran bahwa hukum tersebut sesuai dengan nilai-nilai yang tumbuh dan berkembang dalam masyarakat sehingga harus ditaati. Indikator terbentuknya suatu kesadaran hukum masyarakat adalah pengetahuan hukum, pemahaman hukum, sikap hukum, dan pola perilaku hukum. Oleh karena itu, penyuluhan hukum merupakan suatu keharusan agar masyarakat memahami sepenuhnya tentang peraturan hukum yang diberlakukan, sehingga dilembagakan dan dijiwai dalam kehidupan masyarakat.

Terdapat dua agenda yang harus dilakukan dalam upaya penguatan budaya hukum pada pelayanan publik, yaitu:

Pertama, meningkatkan kemampuan struktur hukum untuk meyakinkan masyarakat bahwa penyelenggaraan pelayanan publik yang dijalankan benar-benar berorientasi kepada rakyat dan berkeadilan sosial serta mampu menjalankan tugasnya secara non-diskriminatif. Artinya, jika struktur hukum dapat meyakinkan masyarakat dan menjalankan tugas dengan baik, maka masyarakat akan memberikan dukungan sekaligus mengikuti pola tersebut dan demikian juga sebaliknya. Terkait dengan peningkatan kemampuan struktur hukum, beberapa prinsip yang harus dipahami dan dilakukan oleh penyelenggara pelayanan publik, yaitu: (1) pelayanan

18 Satjipto Rahardjo, Penegakan Hukum: Suatu Tinjauan Sosiologis, Yogyakarta: Penerbit Genta Publishing, 2009, hlm. ix.

19 Solly Lubis, Politik dan Hukum di Era Reformasi, Bandung: CV Mandar Maju, 2000, hlm. 31-32. 
Didik Sukriono: Penguatan Budaya Hukum dalam Penyelenggaraan Pelayanan Publik sebagai Upaya Penegakan Hak Asasi Manusia (HAM) di Indonesia

publik merupakan hak dasar bagi warga negara yang harus dipenuhi oleh negara. Hal ini dilakukan karena pelayanan publik merupakan bagian yang tak terpisahkan dari kewajiban negara untuk menyejahterakan rakyatnya. Pelayanan publik bukan semata-mata menyiapkan instrumen bagi berjalannya birokrasi untuk menggugurkan kewajiban negara, melainkan lebih dari itu, merupakan esensi dasar bagi terwujudnya keadilan sosial; (2) fungsi negara adalah melindungi segenap bangsa Indonesia dan seluruh tumpah darah Indonesia, mencerdaskan kehidupan bangsa, dan ikut melaksanakan ketertiban dunia berdasarkan kemerdekaan dan perdamaian abadi; (3) pelayanan publik merupakan sebuah kewajiban negara (state obligation) bukan semata-mata memenuhi unsur-unsur formal belaka, melainkan juga secara esensial pemenuhan pelayanan publik juga merupakan pemenuhan akan hak-hak ekonomi, sosial, dan budaya yang melekat pada individu warga negara; (4) pegawai negeri (pemerintah-birokrasi) diadakan tidak untuk melayani dirinya sendiri, tetapi untuk melayani masyarakat serta diharapkan mampu menciptakan kondisi yang memungkinkan setiap anggota masyarakat untuk bisa mengembangkan kemampuan dan kreativitasnya demi tujuan bersama. ${ }^{20}$

Kedua, penyelenggara pelayanan publik harus menciptakan masyarakat yang terdidik (educated public) agar masyarakat dapat memahami hukum pelayanan publik dengan baik dan melaksanakan aturan hukum pelayanan publik serta dapat memberikan saran dan pengawasan kepada instansi yang berwenang. Adapun agenda penguatan budaya hukum yang harus dilakukan oleh penyelenggara pelayanan publik adalah: (1) membangun sistem informasi pelayanan publik yang meliputi penyimpanan, pengelolaan, dan mekanisme penyampaian informasi dari penyelenggara kepada masyarakat dan sebaliknya; (2) meningkatkan upaya publikasi, komunikasi, dan sosialisasi penyelenggaraan pelayanan publik; (3) mengembangkan pendidikan dan pelatihan hukum pelayanan publik; dan (4) memasyarakatkan citra dan keteladanan-keteladanan penyelenggaraan pelayanan publik. ${ }^{21}$

Konkretnya, upaya penguatan kesadaran hukum pelayanan publik, dapat dimulai sejak penyusunan Standar Pelayanan, penetapan Standard Operating Procedures (SOP), pengembangan survei tentang kepuasan penerima layanan, pengembangan sistem pengelolaan pengaduan, sampai dengan evaluasi dan pemberian penghargaan. ${ }^{22}$ Masyarakat diharapkan juga aktif membentuk lembaga pengawasan

20 Agus Fanar Syukri, "Tinjauan Sosio-Teknologi atas Penerapan Standar Pelayanan Publik di Kabupaten Jembrana Bali”, Jurnal Standarisasi, Volume 9, No. 2, 2007, hlm. 69-75.

21 Jimly Asshiddiqie, Konstitusi dan Konstitusionalisme Indonesia, Jakarta: Konstitusi Press, 2005, hlm. 387.

22 Standar Pelayanan, yaitu suatu komitmen penyelenggaraan pelayanan untuk menyediakan pelayanan dengan suatu kualitas tertentu sesuai harapan-harapan masyarakat dan kemampuan penyelenggara pelayanan; Standard Operating Procedures (SOP), yaitu untuk memastikan bahwa proses pelayanan dapat berjalan secara konsisten; Pengembangan survei tentang kepuasan penerima layanan, yaitu suatu mekanisme penilaian kepuasan masyarakat atas layanan yang diterima dari penyelenggara pelayanan; Pengembangan sistem 
Didik Sukriono: Penguatan Budaya Hukum dalam Penyelenggaraan Pelayanan Publik sebagai Upaya Penegakan Hak Asasi Manusia (HAM) di Indonesia

pelayanan publik dan mengadukan penyimpangan dalam penyelenggaraan pelayanan publik kepada Penyelenggara, Ombudsman, dan/atau Dewan Perwakilan Rakyat, Dewan Perwakilan Rakyat Daerah Provinsi, dan Dewan Perwakilan Rakyat Daerah Kabupaten/Kota. Pengaduan dapat dilakukan terhadap penyelenggara yang tidak melaksanakan kewajiban dan/atau melanggar larangan dan pelaksana yang memberi pelayanan yang tidak sesuai dengan standar pelayanan. ${ }^{23}$

Bentuk kegiatan lain yang juga memiliki nilai strategis sebagai upaya penguatan budaya hukum masyarakat adalah model yang dikemukakan oleh Urban Institute dan USAID, ${ }^{24}$ yaitu:

1. Penerbitan newsletter secara regular, misalnya mingguan, dua mingguan, atau bulanan yang berisi aktivitas-aktivitas penting menyangkut masalah pelayanan publik yang dilakukan oleh pemerintah daerah. Newsletter ini biasanya diberikan secara gratis kepada masyarakat luas dengan menempatkannya di tempattempat strategis yang mudah dijangkau, misalnya di tempat-tempat yang sering dikunjungi masyarakat.

2. Pertemuan warga dengan pemerintah dan DPRD yang dilakukan secara berkala.

3. Menggunakan media massa untuk melakukan konferensi pers, memberikan press release, dan mengundang wartawan untuk memberitakan penjelasanpenjelasan pemerintah mengenai isu-isu penting dalam masyarakat atau yang menyangkut masalah publik.

4. Membuka saluran kritik dan saran untuk pemerintah daerah, baik melalui surat, telepon, e-mail dan lain sebagainya.

5. Menerbitkan brosur-brosur pemberitahuan kepada masyarakat tentang pemerintah daerah, misalnya tentang organisasi dan fungsi pemerintah daerah yang dilengkapi dengan nomor telepon sehingga masyarakat dapat melakukan kontak langsung dengan pejabat pemerintah.

6. Talk show atau wawancara melalui TV atau radio lokal untuk membahas masalah-masalah lokal yang ada di daerah.

7. Public hearing dengan berbagai topik, misalnya masalah pembiayaan pelayanan publik, kualitas pelayanan publik, dan sebagainya.

8. Membentuk semacam lembaga perwakilan yang menampung aspirasi anakanak muda dan menggunakan forum ini untuk mendiskusikan masalah demokrasi dan lain-lain yang harus dikembangkan dalam negara demokratis.

pengelolaan pengaduan, yaitu pengaduan masyarakat merupakan sumber informasi bagi upaya-upaya pihak penyelenggara pelayanan untuk memperbaiki kesalahan-kesalahan yang mungkin terjadi.

23 MP3 Masyarakat Peduli Pelayanan Publik, Ada Apa dengan UU No. 25 Tahun 2009 tentang Pelayanan Publik?, Yayasan TIFA, hlm. 10.

24 Erwan Agus Purwanto, "Pelayanan Publik Partisipatif”, Op. cit. , hlm. 176-228. 
Didik Sukriono: Penguatan Budaya Hukum dalam Penyelenggaraan Pelayanan Publik sebagai Upaya Penegakan Hak Asasi Manusia (HAM) di Indonesia

9. Mengadakan festival daerah sebagai sarana untuk mengintegrasikan masyarakat dengan cara berkumpul dan mendiskusikan masalah-masalah daerah.

10. Membentuk tim khusus di pemerintah daerah untuk menangani masalah peningkatan partisipasi masyarakat.

11. Membuat forum 'Anda bertanya Kami menjawab' yang diterbitkan di media massa lokal untuk berinteraksi dengan masyarakat tentang keluhan dan masalah yang dihadapi masyarakat.

12. Melakukan survei untuk menjaring aspirasi masyarakat.

13. Membentuk program-program kemitraan bersama masyarakat dengan fokus utama mencari cara memecahkan masalah-masalah khusus yang dihadapi oleh masyarakat.

14. Membuat Citizen dan LSM Charter, yaitu kesepakatan antara pemerintah dengan masyarakat atau LSM untuk melakukan aktivitas bersama guna memecahkan masalah yang dihadapi pemerintah dan masyarakat.

15. Membuat mekanisme untuk menyediakan dana bagi program-program yang muncul atas inisiatif masyarakat.

Model lain yang juga dapat dijadikan rujukan adalah dengan pelembagaan kontrak pelayanan (service charter) ${ }^{25}$ dalam penyelenggaraan pelayanan publik. Urgensi kontrak pelayanan dipicu oleh beberapa pertimbangan. Pertama, untuk memberikan kepastian pelayanan meliputi waktu, biaya, prosedur, dan cara pelayanan; kedua, memberikan informasi mengenai hak dan kewajiban pengguna layanan, penyedia layanan, serta stakeholders lainnya dalam keseluruhan proses penyelenggaraan pelayanan; ketiga, untuk mempermudah pengguna layanan, warga dan stakeholders lainnya dalam mengontrol praktik penyelenggraan pelayanan; keempat, untuk mempermudah manajemen pelayanan memperbaiki kinerja pelayanan: kelima, untuk membantu manajemen pelayanan mengidentifikasi kebutuhan, harapan, dan aspirasi pengguna layanan serta warga dan stakeholders lainnya.

Kusumasari ${ }^{26}$ menyebutkan terdapat beberapa keuntungan melakukan pelembagaan kontrak pelayanan, yaitu:

1. Mendorong perubahan struktur birokrasi seperti perubahan prosedur pelayanan dan posisi pengguna jasa.

25 Puskesmas Bendo Kota Blitar adalah salah satu daerah yang cukup berhasil mengubah pelayanan publik dengan menggunakan kontrak pelayanan.

26 Bevaola Kusumasari, "Kontrak Pelayanan dalam Reformasi Pelayanan Publik di Indonesia”, dalam buku Birokrasi Publik dalam Sistem Politik Semi Parlementer, yang disusun oleh Erwan Agus Purwanto dan Wahyudi Kumorotomo, Yogyakarta: Gava Media, 2005, hlm. 87-98. 
Didik Sukriono: Penguatan Budaya Hukum dalam Penyelenggaraan Pelayanan Publik sebagai Upaya Penegakan Hak Asasi Manusia (HAM) di Indonesia

2. Pengguna jasa layanan, civil society organization (CSO), dan media massa dapat melakukan peran kontrol dalam penyelenggaraan pelayanan publik karena adanya mekanisme komplain apabila pelayanan publik tidak sesuai dengan standar.

3. Mendorong perubahan mindset dan perilaku aparat birokrasi menjadi lebih berorientasi kepada kepentingan publik.

4. Visibilitas tinggi karena melibatkan partisipasi dan aspirasi masyarakat, LSM, dan DPRD dalam menyusun prosedur, peraturan, dan standar kinerja pelayanan.

5. Melindungi masyarakat dari perilaku birokrasi yang sewenang-wenang maupun sikap arogansi aparat birokrasi terhadap pengguna jasa.

6. Adanya transparansi waktu, biaya, dan prosedur pelayanan.

7. Adanya kejelasan SDM yang menangani suatu pelayanan dan kualitas SDM yang lebih baik.

8. Menciptakan etika dan budaya pelayanan yang menempatkan pengguna jasa sebagai subjek pelayanan.

\section{E. Penutup}

Secara konsepsional, penegakan hukum pada hakikatnya merupakan variabel yang mempunyai korelasi dan interdependensi antara faktor-faktor substansi, struktur, dan kultur (budaya). Ketiga komponen tersebut merupakan suatu sistem, artinya komponen-komponen itu akan sangat menentukan proses penegakan hukum dalam masyarakat dan tidak dapat dinafikan satu dengan yang lainnya. Artinya, upaya mewujudkan kualitas penyelenggaraan pelayanan publik yang hanya bertumpu pada pembenahan aspek substansi dan struktur hukum, dapat dipastikan napas dan amanat UUPP tidak dapat ditegakkan.

Partisipasi masyarakat dalam pelayanan publik merupakan hak sekaligus kewajiban yang dimulai dari perencanaan sampai dengan evaluasi. Partisipasi masyarakat akan mampu menjamin keadilan demokrasi, yakni semua warga negara akan diperlakukan sama dalam sebuah penyelenggaraan negara dan berimplikasi pada persamaan hak akses dalam proses penyelenggaraan pemerintahan. Prinsip keadilan demokrasi dalam penyelenggaraan pemerintahan merupakan hak asasi bagi warga negara yang kemudian berimplikasi pada kewajiban setiap negara untuk menjamin keberlangsungannya.

Agenda yang harus dilakukan dalam penguatan budaya hukum dalam penyelenggaraan pelayanan publik, yaitu: (1) meningkatkan kemampuan struktur hukum untuk meyakinkan masyarakat bahwa penyelenggaraan pelayanan publik yang dijalankan benar-benar berorientasi kepada rakyat dan berkeadilan sosial serta mampu menjalankan tugasnya non-diskriminatif; (2) penyelenggara pelayanan 
Didik Sukriono: Penguatan Budaya Hukum dalam Penyelenggaraan Pelayanan Publik sebagai Upaya Penegakan Hak Asasi Manusia (HAM) di Indonesia

publik harus menciptakan masyarakat yang terdidik (educated public) supaya masyarakat dapat memahami hukum pelayanan publik dengan baik dan melaksanakan aturan hukum pelayanan publik serta dapat memberikan saran dan pengawasan kepada instansi yang berwenang.

\section{Daftar Pustaka}

\section{Buku}

Agus Dwiyanto, Mewujudkan Good Governance, Gajah Mada, Yogyakarta, 2005.

Agus Dwiyanto (et.al.), Kinerja Tata Pemerintahan Daerah di Indonesia, PSKK UGM Bekerja sama dengan kemitraan, Yogyakarta, 2007.

Agung Hendarto dan Nizar Suhendra, Good Governance dan Penguatan Institusi Daerah, Masyarakat Transparansi Indonesia (MTI), Jakarta, 2002.

C.F.G. Sunaryati Hartono, Panduan Investigasi untuk Ombudsman Indonesia, Jakarta, 2003.

Chambliss William J., dan Robert B. Seidman, Law, Order and Power, AddisonWestley, Mass, 1971.

Erwan Agus Purwanto dan Wahyudi Kumorotomo, Birokrasi Publik dalam Sistem Politik Semi Parlementer, Gava Media, Yogyakarta, 2005.

Huntington, Samuel P. dan Joan Nelson, Partisipasi Politik di Negara Berkembang, Rineka Cipta, Jakarta, 1994.

Jimly Asshiddiqie, Konstitusi dan Konstitusionalisme Indonesia, Jakarta, Konstitusi Press, 2005.

M. Ryaas Rasjid, Desentralisasi dalam Menunjang Pembangunan Daerah dalam Pembangunan Administrasi di Indonesia, Pustaka LP3ES, Jakarta, 1998.

Mp3 Masyarakat Peduli Pelayanan Publik, Ada Apa dengan UU No. 25 Tahun 2009 tentang Pelayanan Publik?, Yayasan TIFA, Jakarta.

Satjipto Rahardjo, Penegakan Hukum: Suatu Tinjauan Sosiologis, Penerbit Genta Publishing, Yogyakarta, 2009.

Sirajjudin, Didik Sukriono dan Winardi, Hukum Pelayanan Publik Berbasis Partisipasi dan Keterbukaan Informasi, Setara Press (Kelompok Insrans Publishing), Malang, 2011.

Soedjono Dirdjosisworo, Pengantar IImu Hukum, CV. Rajawali, Jakarta, 1984.

Solly Lubis, Politik dan Hukum di Era Reformasi, CV. Mandar Maju, Bandung, 2000. 
Didik Sukriono: Penguatan Budaya Hukum dalam Penyelenggaraan Pelayanan Publik sebagai Upaya Penegakan Hak Asasi Manusia (HAM) di Indonesia

\section{Dokumen Lain}

Abdul Mukthie Fadjar, "Keprihatinan Memudarnya Penegakan Hukum dan Kewibawaan Hukum di Indonesia", Makalah disampaikan pada sarasehan Forum Doktor Fakultas Hukum Universitas Brawijaya, 30 Juni 2011.

Agus Fanar Syukri, "Tinjauan Sosio-Teknologi atas Penerapan Standar Pelayanan Publik di Kabupaten Jembrana Bali", Jurnal Standardisasi, Volume 9, No. 2, 2007. Irfan Islamy, "Membangun Masyarakat Partisipatif", Jurnal Administrasi Publik, Vol. IV, No. 2, 2004.

Rival G. Ahmad (et.al.), "Dari Parlemen ke Ruang Publik: Menggagas Penyusunan Kebijakan Partisipatif", Jurnal Hukum Jentera Edisi ke 2, PSHK, Jakarta, 2003. Kompas, "Kerusakan Moral mencemaskan", 20 Juni 2011. 